\title{
Membranectomy with optic capture in a paediatric patient with VAO
}

\author{
Sudarshan Khokhar, Deeksha Rani 지 , Antriksh Wahi, Debarun Sharma
}

Ophthalmology, Dr Rajendra Prasad Centre for Ophthalmic Sciences, AlIMS, Delhi, India

\section{Correspondence to} Dr Deeksha Rani; deekshamedico@gmail.com

Accepted 30 December 2021

\section{DESCRIPTION}

Visual axis opacification (VAO) is a common complication of paediatric cataract surgery. ${ }^{1}$ Posterior continuous curvilinear capsulorhexis (PCCC) and good anterior vitrectomy are known to reduce the prevalence of VAO. Inadequate anterior vitrectomy may be a cause of VAO, where retained anterior hyaloid phase may act as a scaffold for proliferation of lens epithelial cells. ${ }^{2}$ Optic capture is another technique that has been described to prevent the formation of VAO. ${ }^{3}$ We describe the case of a 4-year-old female child with operated lens aspiration with PCCC with anterior vitrectomy with a three piece intraocular lens (IOL) in the sulcus, and presented to us with clinically significant VAO.

The 4-year-old pseudophakic female child was referred to our centre for management of a visually significant VAO in the left eye. Antenatal history was uneventful. The child was born at full term by lower segment caesarean section in view of oligohydramnios. She had a birth weight of $3 \mathrm{~kg}$. There was no history of neonatal intensive care unit (NICU) stay in postnatal period. She is a known case of cerebral palsy (mixed type) with global development delay. She was diagnosed with unilateral cataract at the age of 2 years and 7 months and was operated for left eye lens aspiration with PCCC with anterior vitrectomy, and a three-piece IOL was placed in the sulcus. On follow-up, she was diagnosed with left-eye VAO, first identified 3 months after surgery. She was referred to our centre for the management of the same.

The child presented to us at the age of 4 years. On distant direct ophthalmoscopy, we found a total cataract in right eye and VAO involving central visual axis in the left eye. The child was scheduled for examination under anaesthesia followed by right-eye lens aspiration with PCCC with anterior vitrectomy with IOL in bag and membranectomy in the left eye in

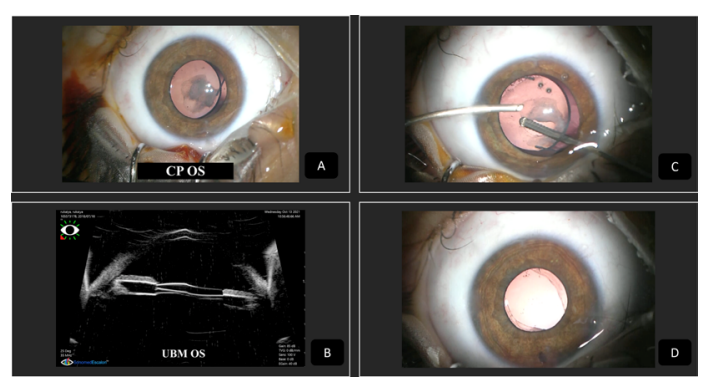

Figure 1 (A) Preoperative clinical picture (CP) of the left eye (OS). (B) Ultrasound biomicroscopy (UBM) showing hyperechoic membrane posterior to IOL. (C) Intraoperative still showing membranectomy. (D) Wellcentred IOL with optic capture. IOL, intraocular lens.

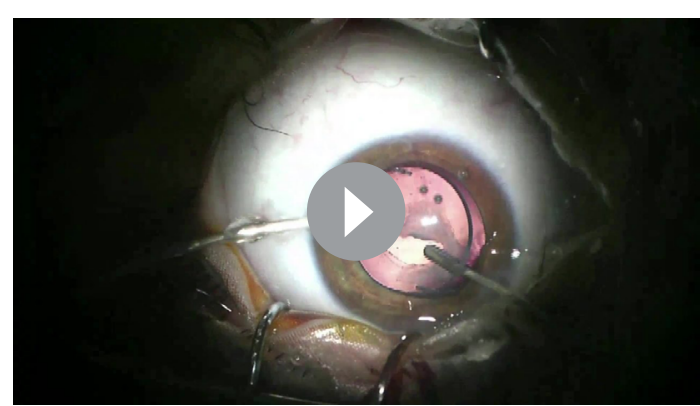

Video 1 Narrated surgical video demonstrating membranectomy with optic capture.

two different sittings. Surgery of the right eye went uneventful. Examination Under Anaesthesia (EUA) findings of the left eye revealed central fibrous VAO (figure 1A) with decentred three-piece IOL in the sulcus. Ultrasound biomicroscopy revealed IOL in the sulcus with hyperechoic membrane posterior to the IOL (figure 1B).

Two $1 \mathrm{~mm}$ side ports were made and viscoelastic was injected in the anterior chamber, and free mobilisation of the IOL was confirmed with sinskey hook. Posterior membrane was removed using anterior vitrector on cut-irrigation/aspiration mode. It was noted that anterior and posterior capsulorhexis margins were adherent to each other. Around $5 \mathrm{~mm}$ opening was made and optic of three-piece IOL was captured behind the sulcus margins. Stability of the IOL was confirmed; irrigation and aspiration of viscoelastic were done and wounds were hydrated (video 1). Postoperative day 1 showed central and stable IOL with a postoperative retinoscopy of $+1.25 \mathrm{D}$ on vertical axis and $+1.75 \mathrm{D}$ on horizontal axis (at $50 \mathrm{~cm}$ ). The child was prescribed spherical equivalent with $+2 \mathrm{D}$ near add and was started on topical antibiotics, steroids and cycloplegics with appropriate tapering. On 1-week follow-up, the visual axis of both eyes was clear with well-centred IOLs in both eyes. The child is kept on follow-up.

\section{Learning points}

- Posterior continuous curvilinear capsulorhexis with inadequate anterior vitrectomy can cause a clinically significant visual axis opacification.

- Three-piece intraocular lens (IOL) placed in the sulcus without optic capture is prone to decentration even in the presence of a good sulcus. Thus, the surgeon must always attempt to capture the optic of IOL while inserting a three-piece IOL. 
Contributors Planning of treatment and conducting procedure: SK. Acquisition of data and video editing: AW and DS. Preparation of the manuscript: DR.

Funding The authors have not declared a specific grant for this research from any funding agency in the public, commercial or not-for-profit sectors.

Competing interests None declared.

Patient consent for publication Consent obtained directly from patient(s).

Provenance and peer review Not commissioned; externally peer reviewed.

Case reports provide a valuable learning resource for the scientific community and can indicate areas of interest for future research. They should not be used in isolation to guide treatment choices or public health policy.

\section{ORCID iD}

Deeksha Rani http://orcid.org/0000-0002-3310-8021

\section{REFERENCES}

1 Vasavada AR, Praveen MR, Tassignon M-J, et al. Posterior capsule management in congenital cataract surgery. J Cataract Refract Surg 2011;37:173-93.

2 Vasavada A, Desai J. Primary posterior capsulorhexis with and without anterior vitrectomy in congenital cataracts. J Cataract Refract Surg 1997;23(Suppl 1):645-51.

3 Xie Y-B, Ren M-Y, Wang Q, et al. Intraocular lens optic capture in pediatric cataract surgery. Int J Ophthalmol 2018;11:1403-10.

Copyright 2021 BMJ Publishing Group. All rights reserved. For permission to reuse any of this content visit

https://www.bmj.com/company/products-services/rights-and-licensing/permissions/

BMJ Case Report Fellows may re-use this article for personal use and teaching without any further permission.

Become a Fellow of BMJ Case Reports today and you can:

- Submit as many cases as you like

- Enjoy fast sympathetic peer review and rapid publication of accepted articles

- Access all the published articles

Re-use any of the published material for personal use and teaching without further permission

Customer Service

If you have any further queries about your subscription, please contact our customer services team on +44 (0) 2071111105 or via email at support@bmj.com.

Visit casereports.bmj.com for more articles like this and to become a Fellow 